\title{
Are the young the Others in Croatian media? - An analysis of newspaper articles about violence among the young
}

The media are an important tool for creating public opinion and they can influence the creation of laws and policy. Media representation of young people is important because it can influence the public image of them and it can also influence the young themselves. On the other side, young people can be discriminated against and treated with suspicion because of a specific media image of them. In this paper we analyse a corpus of newspaper articles about violence among the young that occurred in Croatia recently. Analysing this discourse we try to find out who the participants are and what they emphasise as the most important questions and issues in connection with the young and violence. We try to find out how the creation of a text is influenced by power relations and other factors connected with the media (i.e. public opinion, stereotypes, public panic) and what the main image of the young created by the media is. We also analyse how language is used and which language and discourse elements (i.e. style, metaphors, and collocations) are used in creating a specific media image of the young.

\section{Context}

Recently, several violent and aggressive conflicts happened among the young in Croatia. The issue became especially discussed after the death of young Luka Ritz, who died because of the consequences of being beaten up by other young people. The death of $L$. $R$. was not the only one in this period, but it attracted greater attention partly because his parents and friends founded a counselling centre and established an annual award named after him, as well as organised concerts in his honour - all with the aim to promote tolerance and non-violence. On 23rd October 2010, the play This could be my street, which is about violence among the young, premiered in ZKM (Zagreb's Theatre of the Young). It is dedicated to L. R. and all other young boys and girls 
who are victims of violence and is a sort of enquiring about relations between characters through their attitudes towards the violent death of a young person ${ }^{[1]}$

The Luka Ritz Counselling Centre was founded under the auspices of the City of Zagreb with the main aim to help young people and their parents in their fight against violence. The other reason for establishing such a centre was that the institutions did not do what they were supposed to do, and that the counselling centre "[would] embarrass the state institutions." These activities resulted in the problem being more discussed in public, ensuring that he (L. R.) "did not remain just a two or three days' news in newspapers. ${ }^{\not 2]}$

\section{Theoretical background}

Youth: Today, it is difficult to establish boundaries between the periods of childhood, youth, and adulthood, and we usually talk about the extended or prolonged period of youth. Although most of the experts agree that the period of youth is between 15 and 30 years of age (Tomić-Koludrović, Leburić), in our analysis the young refer first and foremost to adolescents. The reason for including only such a narrowly defined group of young people is that the violent act that triggered the debate happened between adolescents.

Violence: It is difficult to define violence even though it is easy to recognise it, judge it, and discuss it. According to Rapport and Overing (380), the word violence has numerous denotations: "violence as unruly behaviour; as an infringement of property or dignity; as vehement conduct; as use of physical force; as physical assault; and as threat or dramatic portrayal of any or all of the above." The definition from the Barnhart and Barnhart Dictionary (2335) states that it is "rough force in action, 2. rough or harmful action or treatment, 3. injury." The Violence Prevention Alliance (VPA), which is part of the WHO organised to prevent violence, defines violence as "the intentional use of physical force or power, threatened or actual, against oneself, another person, or against a group or community, that either results in or has a high likelihood of resulting in injury, death, psychological harm, maldevelopment, or deprivation." According to Knežić (48), violence is a kind of phenomenon/process; it can be a social reality or abstract matter of thinking.

Influence of the media: The media are an important part of contemporary life and their influence is strong because of many reasons; one of them is that they can reach almost everybody, especially 
through the Internet, and that using different media takes up the greatest amount of free time ${ }^{[3]}$ According to Thompson et al (410), the media can "penetrate every aspect of social life," but as they suggest, "crime news has long been and continues to be an information priority for the media."

[4] Violent behaviour of adolescents is an interesting topic and concern of contemporary society; however, the media presentation of the problem is very often distorted (Earls 4; Krisberg et al 7). We can agree with Vromen that "politicians only consider young people when they present a problem “[5] The question of media influence is especially important when discussing the impact of violence presented in the media ${ }^{[6]}$

The influence of the media on the young is connected with the image of them created by the media and their position in the media. Some research shows that the young are very rarely the main or only actors, as well as co-actors, in TV programmes or in the printed media; even in topics which are of interest to the young, there are no young people at all (Turjačanin et al 15,17,46; Ilić Šunderić et al $6,14,27)$. In Croatia, the situation is similar; none of the three main television stations have a special programme for the young between the ages of 15 and 30 (Kladar 116) and only in $20 \%$ of texts the source of information are children (Kanižaj 18).

The issue of juvenile violence is frequently reported in newspapers (Mediacentar 15,16; Gilliam and lyengar, "Super-Predators" 152), but the relevance of the news (and the problem itself), however, is very small because texts are rather short, situated on last pages, usually in the traffic accidents and crime news section (in Croatian, Crna kronika or 'Black Chronicle'). Very often, the problem of juvenile violence is presented in a sensationalist manner and the young are presented in a negative and stereotyped way, as, for example, super-predators (Anderson 1181; Pizzaro et al).

\section{Methodological aspects of analysis}

In the analysis of newspaper texts we have used certain elements of critical discourse analysis (CDA). According to Van Dijk ("News Analysis" 1,2), "news reports, whether in the press or on TV, constitute a particular type of discourse", which is a specific kind of socio-cultural practice.

Discourse is a linguistic and a social process connected with the situation, institutions, and social elements which shape it. CDA sees discourse as a complement of language elements that have an 
underlying ideology. Using the concepts of CDA, we have analysed the discourse of newspaper articles in order to understand how the writers of the articles promote their own ideas and present the young by means of language elements, e.g. metaphors, paraphrases and collocations, and through the use of topics, content, context, and the structure of text.

Apart from CDA, we have also used certain aspects or elements of content analysis - which is a quantitative method involving counting phenomena in texts - in order to support our arguments and conclusions gained in doing CDA (Stokes 56).

\section{Data}

Our corpus consists of texts about violence among the young in connection with Luka Ritz. We have collected articles published between July 2008 and December 2010 in daily newspapers Jutarnji list and Večernji list, and on web sites www.index.hr and www.tportal.hr, mostly. The articles in our corpus are about the death of L. R. and his funeral, the police search for the attackers, and their trial. Commentaries about the problem of juvenile violence and news articles about different activities that government bodies and non-governmental organisations did in the memory of L. R. and other victims of violence have also been included.

A total of around 80 articles have been included in the analysis. The attack on L.R. occurred on 1st June 2008 but nothing was mentioned in the daily newspapers, not even in the sections dealing with traffic accidents and crime news. The first articles appeared on 16th June; afterwards, articles were published in different intervals, usually as a result of activities connected with L.R.

Some of the articles are news articles, only giving information (not containing comments or expressing attitudes or opinion), and these were mostly repeated, or copy-pasted, from one newspaper and web site to the other. In these articles even the same sentences (and some mistakes) are found. Other articles are written in a form of commentaries; they are journalists' signed comments and are personalised, with expressed attitudes and opinions.

\section{Analysis}

Newspaper texts can be analysed on different language levels, the grammatical one - including semantic structures - and on higher levels, such as coherence between sentences, overall topics, 
stylistic and rhetorical elements. We have analysed the data following these general elements of discourse. We have tried to find out what kind of image of the young is given and how the main participants of the discourse use different language elements in order to produce such an image. The main argument we have tried to prove here is that the image of violent youth is rather complex because it is deeply contextualised, i.e. it depends on the position and ideology of the main actors and the context (first and foremost, the topic), so the young are depicted in a stereotyped and mostly negative way in certain situations, while in others they are presented in a less negative and more "victimised" manner.

Coherence of the text: The language used is a written language, with complex sentences and strong coherence between them. A text is coherent if it describes a sequence of events, such as situations, acts, and its participants in such a way that one sentence refers to the previous or following one (Van Dijk, "News Analysis" 12). In our data, text coherence has been achieved through the use of different referents for the participants introduced in the preceding sentence (such as they, them) or by repeating the terms used for the victim and the attackers, e.g. a highschool senior, hooligans, a furious group, gang, a young bully, a delinquent. In some of the texts the coherence has also been achieved through the following basic narrative structure: after the headline there is the summary, while in the body of the text we can easily distinguish between the following parts: the setting of the event, the problem (or complication), the climax, resolution or its consequences, evaluation and opinion (Ochs 195).

Syntactic analysis and semantic roles: Sentence syntax, e.g. the use of active or passive forms, relational functions (subject and object), word order, etc., can show the semantic roles of participants of the described events (Van Dijk, "News Analysis" 11). Accordingly, the syntax of the sentences in a discourse depends on the semantic roles and it reveals them, as well as the position of the writer. Syntactic elements also depend on the functional style of the discourse. The use of nominal and participle constructions is quite frequent in Croatian journalistic style (Barić et al 274).

In our data, the young offenders are presented as agents and are usually put in the first (subject) position in the sentence (mainly as subjects of an active sentence) ${ }_{,}^{[7]}$ e.g. Killer of Luka Ritz enjoys freedom; Killers of Luka Ritz play music, dance and laugh in front of the courthouse; Killers of Luka 
Ritz state to the police that they attacked him out of pure boredom. In other news texts and commentaries the offenders are again in the first subject position in the sentences but are followed by a passive form or a nominal predicate, e.g. Ritz's killers released to await trial; Killers of Luka Ritz are not the exception but the tragic rule; Underage attackers on Ritz also detained in custody; Five suspects for attacking Luka Ritz in front of a juvenile court judge. In the first group of examples the offenders are assigned a prominent role, marking them as subjects of the active sentences, while in the second group the role assigned to them is less prominent and less active.

Such different roles assigned to the same participants reveal the perspective of the writers, who once see them as active doers of the violent act, and as less active in other situations. In the first situation they are presented in a negative way, as guilty and as "cold-blooded murderers",[8] while in the other they are depicted as guilty, but their role is passive and the picture presented is a less negative one. These differences are also connected with the main topics of these texts. The first group of examples consists of the headlines of articles dealing with the act done by the young offenders (in which the very act of beating the victim is described) therefore it is to be expected that they are presented as active, while the second group is made up of the headlines of articles about the trial and commentaries, which discuss the social and public context of this act of violence as well as violence in general and analyse the problem in a way more complex than just giving information. The syntactic analysis of these few examples already proves our main argument. There are certain differences between the syntax in informative (or news) texts and other types of texts. In informative texts, sentences are usually shorter, but syntactically correct, while in other types of texts they are longer and more complex, containing incorporated clauses, but syntactically they are "less correct" because they use elements of both the written and the spoken language (e.g. One kills, all are silent. Who refuses is a castaway).

Lexical choice: Certain elements of vocabulary and phrases used in our corpus are different depending on the kind and style of the texts and the topics. In informative texts about the violent act the writers use formal words, and words and phrases from police and criminal justice jargons (e.g. physical attack, statement, the first accused, detainee, detained in custody). In commentaries and articles, where the problem is analysed and put in a broader social context, there are more colloquialisms and the language is less formal. The writers of these more "personalised" 
discourses use language and vocabulary more typical for spoken situations, e.g. freak, kid, bad boys (frajeri), gang (škvadra), kicking (cipelariti).

Lexical items used for naming the victim and the defendants can show how they are seen by the journalists and other writers, as well as by institutions and, later (under the influence of the media discourse), by the public.

"Lexical" representations of the victim and the offenders: There is always a very strict lexical difference between the victim and the offenders. The victim is almost always called a high-school senior while the attackers are most often young men. In texts about the victim the terms vary high-school senior, young man and a child - but the difference is evident when he is mentioned in the same text with the offenders. In those cases L. R. is always presented as a victim.

A possible reason why he is referred to as a high-school senior could be an attempt to elicit sympathy for the victim: stressing that he was finishing his secondary school creates an image of a young person at the beginning of his life; however, only little information about him is given. He is described as "a young man whose name has become a symbol of the struggle against violence among the young. L. R. has become a symbol of the struggle against street violence. [...] a quiet and good guy dressed in a heavy metal T-shirt." ${ }^{\text {[9] }}$ After presenting such an image of the victim the tragedy seems greater and the problem of violence represented as a really important and crucial issue.

From the photographs of the victim published in different articles it can be seen, first and foremost from his appearance, that he was probably a member of a rock or heavy-metal sub-cultural group, but this notion is mentioned only twice and only by his friends, who state that "he was not beaten because of 3 kuna in his pocket, but because of his long curly hair, because of which he was marked as a metal musician or a rocker":[10] This is interesting because these subgroups are quite stigmatised in Croatian society; in our data, only one writer comments on different subgroups and their mutual relations and elements of their way of living. At the same time this is the only instance when the young are interviewed about the problem of juvenile violence and are able to express their attitudes and experiences. 
Such unsaid elements, which can be read between the lines, are as important as the labels and names used for the victim and the language used when speaking of him. We can only suppose that this element of the victim's identity is not mentioned in order to avoid damaging the image of a "good young boy beaten up for nothing," as if the tragedy of a lost young life would be of less importance because he was a member of an unpopular subgroup; they are not mentioned in order to support the already established image of the victim. We can also speculate that exactly this information about the victim is left unsaid in order not to imply that the act could have been a fight between two opponent subgroups; as if it had been a fight between members of different subgroups, it would be less "difficult" or the violent adolescents would be seen as less "guilty." We could argue that by not mentioning these parts of the victim's life the writers try to present the violent act as even more senseless and cruel, stressing that it was not provoked by the victim himself or his attitude, or anything else. With this, the "guilt" is more stressed and the young violent men are presented in an even more negative light and seen as even more violent because they have beaten up another human being without any reason.

It is important to stress that while the friends of L. R. believe that he was not beaten because of money, in two other instances exactly the opposite is stated; the headline of an article reads Beaten up because of two kuna, and of another Death on the street because of only three kuna. While there are only two words used for L.R., there are many different terms used for the attackers (43 different terms), e.g. young men or hooligans, furious group, gang, young bully, delinquent, the five (Cr. petorka), the four (Cr. četvorka), abuser, suspect, arrested, attacker, offender, Luka's killers, killers, person under age, person of age, 16/17-year-old, teenager, bad boy (Cr. frajerčić), abusive person, maniacs, monsters, idiots, child/children, kid(s), boys.

Some of the terms are neutral, while others are quite negative. These terms vary, e.g. both negative and neutral terms are used in the news texts; there are more negative terms in the articles about the attackers, while neutral terms and the terms from legal and police jargons are used more often in the texts about the trial and verdict. In the texts discussing the problem of juvenile violence, in which statements from experts and public workers are included, more neutral terms are used and there are almost no negative labels (especially no very negative ones such as killers). Slang is used more often in commentaries. 
The main difference in using labels for the violent adolescents is not in using neutral or negative terms in one group of texts and not in another, but in the frequency of these labels in different texts. The word child, for example, is used both in the articles about L. R. and in those about violence among the young in general. In the texts about the violent act it is used only when quoting the parents and social workers, while in the texts that describe the act itself the term child or children is used to a lesser extent; terms such as attackers, hooligans, killers and the initials of the names of the suspects are used more often in these texts. Using different names for the offenders in different contexts, they are represented as bullies, killers (and as guilty) on the one hand, or as victims of the system, society, justice, etc. on the other. In relation to the context, they are discursively criminalised or victimised. As a good illustration for such variation of the terms for the young offenders, the next example is used: "This is how one of these minors explains why he has stopped visiting the social worker every week: 'I went there a few times, but l've stopped. Going there is stupid when every time she asks me if I have had my identity card issued'. If what the young man said is true, the attitude of the social worker towards the child heavily burdened with traumas... ${ }^{\circledR 11]}$

Such different representation of the attackers is context dependent; it depends, for instance, on the topic or the theme of the texts, the main actors, and the position of the writer, and again supports the main argument. In the articles discussing the reasons for such behaviour, the attackers are victims and are not considered accountable for their violence. In the articles about the violence against L. R., they are presented negatively, as aggressive and problematic adolescents, but there are not many comments oriented towards the criminalisation of the attackers ${ }^{[12]}$

In order to confirm the observation that negative labels for the young offenders are more frequently used in some of the texts, while more neutral terms are used in others, depending on context, we have counted the occurrences of these labels and calculated the percentage of the labels used. The results show that the labels most often used for the violent young persons are young men (14\%) followed by minors (12\%). These terms are neutral and primarily identify a person's age. All together, terms that identify the attackers as young people are most frequently used - in addition to young men and minors, there are the following terms: young, juveniles, then child, and terms for the exact age, e.g. 15-year-old boy, 16-year-old boy, etc. These terms are used in almost $40 \%$ of 
all cases. Thus, the age of the attackers is the most stressed element of their identity and, accordingly, the most important for the authors of the discourses. This is expected because the main topic is juvenile violence and not violence in general. This could also be seen as a way of distancing and expressing a clear opposition between the writers of the texts and the young.

The next most frequent terms are the attacker and initials of the names, each used in $8 \%$ of all situations. Negative terms that are used most often are killer (6\%) and hooligan (around 6\%). In comparison to other terms, the neutral ones are used more often. Even though negative terms are used less often, there are much more different negative terms than neutral ones; besides hooligans and killers there are others, e.g. bully, delinquent, gang, criminal, idiot, cretin, etc. These figures support the main argument that the image of the young is varied and context depended.

Discursively constructed image of the young: Some elements of the context on which the image of the identity of young people depends are: place, writer of the text, and the theme or topic; the use of language elements is, naturally, in accordance with it. The neighbours of the attackers, for instance, saw them as good and kind boys: “The neighbours of the New Zagreb's five don't feel threatened. For them, S. S., M. K., K. M., R. L. and J. J. are still nice boys from their building, who always greet politely in the lift. For the rest of Croatia, they are - Luka's murderers. ${ }^{[13]}$

“They are not wealthy, but they are not hungry either. They don't distinguish themselves in anything; they fit into the picture of an average working family. ${ }^{[14]}$

The discursive image of the young is even more complex. In the articles about who is to blame, the violent youths are represented as victims of society, crisis, neglect, inadequate school and justice system. Different arguments and stereotypes are used to support these ideas.

"[...] aggressive kids live mostly in urban environments. They come from dysfunctional families with bad interpersonal relations, and often live with only one parent. Court practice shows that young bullies, before beating somebody, were known to the police for theft. ${ }^{[15]}$ 
"What the children from problematic families and with too busy parents have in common is that they are left to themselves. Both groups are at risk of becoming bullies. ${ }^{[16]}$

"The society with such a distorted list of values and unsuccessful educational system, saturated with apathy and hopelessness, is fertile ground for an increase in the number of hooligans, bullies and criminals. ${ }^{[17]}$

"The recession itself changes relations in society, and negatively influences relations between children and parents."

"Violence among the young in Croatia has become a completely normal way of behaving, because parents do not have time for their children and do not know how to deal with them, because the system does not have the will or the personnel to deal with aggressive behaviour; but, most importantly, in the present-day world, goodness is not stressed or practiced, and the main heroes of the society are those [...] who behave as anti-heroes... ${ }^{[18]}$

"In the last 20 years, we have been occupied with a lot of different things in Croatia, except with our children, so the young now repay us for this neglect", concluded M.V.

"The school has neglected its educational function. [19]

This search for the guilty party was in fact an attempt to shift responsibility - the parents of the violent young persons blamed the society and inadequate schools and, after the trial, even the legal system and the social service. On the other hand, experts blamed families which neglected their children, as well as the crisis influencing the change of the values in society. Through such discourse about the problems which underlie violent behaviour, the young are seen as passive and as victims without the possibility to change things to their benefit. 
Discursive construction of the violent act: Providing potential motives for such an attack and the way the incident is presented are another important element in depicting the young. The ideas that the victim was "beaten up just out of pure boredom" or that "they [the attackers] started to provoke without reason" are expressed in some of the texts. The act is described as a wanton murder. The statements that L. R. was attacked out of boredom are also used in headlines in order to shock and attract the attention of possible recipients of the discourse.

Different terms are used to label the incident, e.g. bloody happening, brutal beating, brutal night attack, fatal attack, cruel attack, to kick (Cr. slang cipelarka), to hold in chancery (Cr. slang držati u kravati), to beat the victim (Cr. slang natabati žrtvu), beating, raging of young bullies, aggressive move, causing serious body injury. The use of different words for the attack shows the attitudes of the writers of the texts, mostly emotional responses. These terms also depend on the context, e.g. in the informative texts about the incident, more formal terms are used, such as bloody happening, brutal/fatal/cruel attack. Terms from police jargon, such as aggressive move, are used in the articles about the trial, while more slang is used in commentaries.

Style choice: The importance of different styles for the lexical choice has already been mentioned in the analysis of the vocabulary and phrases used in the discourse. Stylistic analysis includes not only variations between different discourses but also the use of language according to the personal and social context. Social factors such as gender, status, power as well as the formality of the situation and the written and spoken language influence the style of the text.

Every functional style has its rules and characteristics that make it recognisable as one or another. Journalistic style is a specific language system maximally adapted to the needs of informing the public, which should be in accordance with the media and genre (Mladenov 31). Usually, there are two main different types of journalist texts; one group is made of texts with the intention to inform and the other of texts with literary elements. ${ }^{[20]}$

The language of the newspaper is more formal and closer to the standard in informative texts (or news), while it is more colloquial and less formal in texts with literary elements (Hudeček 63). Because of this thematic diversity the language and the style of the newspaper is very diverse and creative and uses different phrases that bring "special significance ... and with that they attract the 
attention of the viewers or readers." (Mihaljević, Kovačević 6) In order to strengthen this significance, slang, jargon and colloquialisms can be used. It is expected to find these elements of vocabulary in certain genres (such as commentaries, review, criticism). We have already seen that slang, jargon and colloquial lexical elements are used in the commentaries and articles that discuss juvenile violence. The reasons for this particular lexical choice can be different, e.g. the choice of vocabulary can be influenced by the topic, the wish to achieve an effect, such as an emotion, or to attract attention or even to shock.

Thematic analysis: The importance of the topic for the lexical and syntactic language choice has already been mentioned, however "the thematic organisation of news discourse plays a crucial role." (Van Dijk, "News as Discourse" 30) The analysed discourses are organised in a similar way. After the headline and summary, longer texts have been divided into several sections with short subheadings. Within different parts of the texts it is possible to distinguish components such as the main event, background and context (including history in certain cases), as well as the opinion of the writer or the actors in the discourse, and comments, which sometimes include a possible solution for the problem.

The most prominent topic is usually the first, often mentioned in the summary or headline, in which the exact theme or opinion, question, quotation etc. directly connected with the topic is expressed, e.g. Finally a court trial for the minors - The three are on trial for the death of Luka Ritz 15 months after the beating on the bridge; Finally found - The attackers on Luka Ritz in custody; Attackers' neighbours say that they are quiet children from the neighbourhood. From these three headlines/subheadings it is easy to see what the main topic of these texts is or what the text is about.

The relevance of the topic is also signalled trough "physical markers" of importance, such as the quantity of the articles about a certain topic and the size of the article and its position in the newspaper. The news articles that contain information about the violent incident or the arrest of the suspects, the verdict and events held in honour of L. R. are usually short articles published in the local section Zagreb or Events in newspapers, and in the section News and sub-section Croatia on web sites. Articles about juvenile violence are usually longer, because these texts include more 
actors, such as experts, parents etc., who are interviewed, and whose opinions and attitudes are included.

On a few occasions, articles were published on the front page of a newspaper, e.g. Victim of hooligans - High-school senior from School of Graphics dies - "Beaten up high-school senior dies during operation" situated in a small box at the bottom of the front page of Večernji list ${ }^{[21]}$ Other articles introduced on the front page were "bigger" and situated in the centre of the page, e.g. Zagreb - The appeal of the new police chief - We need help from schools, the Church and parents. ${ }^{[22]}$ From these few examples we can see that different topics were more relevant for writers and their institutions on different occasions because they were published on the front page. Two most frequent topics in our corpus are the violent attack on L. R. (its description), and the description of the custody and trial of the attackers. Both these topics provoked a heated public debate that included legal, police and public attitudes and opinions about violence among the young, which also became an important issue. Different events were organised in order to promote non-violent behaviour and the starting of the Counselling office was the main topic of other articles. Discourses about juvenile violence which included interviews with experts and public workers (e.g. spokespersons of the court and the police) and journalist commentaries stressed the escalation of violence among the young and a kind of a "search" for the scapegoat (mostly recognised in the society, inadequate laws, schools, crisis, parents who neglect their children, social service).

Rhetorical analysis: The style, the use of specific language elements and the way a topic is presented and structured can also have rhetorical functions. The informative texts try to be objective, which is accomplished by the use of exact dates and detailed context. The use of numbers, e.g. how many young victims there were in a certain period, and how many of them died because of the consequences, as well as statistical data about juvenile violence are also an important part of news articles and give them objectivity and seriousness.

Analysing our corpus, we have not found a lot of rhetorical elements, but its "atmosphere" is indicated in the way a topic is presented, in lexical choices, the style and organisation of the text. The use of strong negative labels for the offenders and the way of describing the violent act give the texts about the violence against L. R., the search for the offenders, and their trial an "air" of a 
crime novel. On the other hand, when dealing with the young offenders and discussing the reasons for violent behaviour and a possible solution for it, lexical choices and the use of other language elements indicate that they are victims and not to be blamed for their problems. In the articles where the parents and friends of L.R. are interviewed, the style of writing and lexical choices provokes compassion of the readers and their sympathy for the victim and his closest ones. According to Van Dijk, one of the main aims of the news discourse is to help the reader to better memorise it, to be persuasive, and, we need to add, to intrigue the reader. In order to persuade the readers to a greater extent, writers use overstatements, exaggerations or understatements and comparisons, metaphors or other rhetorical elements.

The use of these rhetorical elements is rather evident in the headlines. The aim of the headline is to draw the attention of potential readers to the text. In order to attract attention, headlines are usually very vivid and often shocking, using paraphrases, slogans, rhetorical figures, and elements from other discourses. Headlines are important because they define the most important or relevant information of the text or news and very often are the only thing that the readers remember. (Van Dijk, "News Analysis" 190)

The headlines in our corpus are usually very explicit, e.g. Violence among the young: Alone, neglected and dangerous!; The young repay with violence for the society's 20-year-long neglect; Shocking Facebook group named 'People annoyed by Luka Ritz' has as many as 437 members. Sometimes the opinion of the writer or other actors is expressed in the headlines, e.g. 'Group against Luka Ritz is highly reprehensible and worrisome'; Members of group 'People annoyed by Luka Ritz' are malicious and insensitive, states children's rights ombudsperson; Attacker on Ritz Judge is to blame for J. J. striking again.

Comments, evaluations and expectations are very often expressed in the headlines in the form of quotation, e.g. The case Ritz: twilight of profession and institutions; Killers of Luka Ritz are not the exception but the tragic rule; Happy birthday, Luka: Will violence among the young ever stop?; We are an exotic country when justice is concerned; Antiheroes become heroes!; Suzana Ritz: We are stronger than violence; Mother of Luka Ritz: State institutions do nothing to prevent violence among the young; Father of attacker on Luka Ritz: You have made a monster of my innocent son; A minor who kills somebody is not a delinquent but a killer. 
Some of the headlines are quite sensationalist and shocking or are trying to provoke emotions and reactions from the readers, usually through the use of hyperbolas and exaggerations, e.g. Brokenhearted parents; My son's hair turned grey during the 90 days in a cell with criminals; Killer of Luka Ritz enjoys freedom; Angels are killed in Zagreb; 'Bullies are really cool (Cr. slang face)'; They decided to beat up Luka out of pure boredom.

Some of the rhetorical figures used in the headlines are metaphors, e.g. Society as fertile ground for the development of hooligans, bullies and criminals, and irony Our beautiful justice Scandalous sentence for killers of Luka Ritz; Faber: We have stepped on the gas. Some of the other figures that are used are oxymoron, Ritz's killers released to await trial: "This is a normal consequence of an abnormal situation" (Normal abnormality), or a kind of antithesis, Last goodbye instead of graduation joy. In the headline The easiness of beating up we can recognise a paraphrased title of the book The Unbearable Lightness of Being by M. Kundera.

Some of the headlines could be understood as trying to provoke a kind of panic in society, e.g. Horror on Zagreb streets - Attacker on Luka Ritz strikes again; Parents are powerless; The most shocking fact is that they are not the only such hooligans; With the sentence for the killers of Ritz we will close our eyes in front of the fact that there are thousands of such kids; Stop the killers and bullies in Zagreb.

Main actors: An important element of CDA is to identify the main actors in a discourse. The main participants or actors in this discourse have already been identified in the analysis. They are first and foremost journalists, who have the possibility to express their opinions, attitudes and to comment on the problem and the events. The spokespersons of police and court, as well as experts such as psychiatrists, psychologists, and sociologists are also included. The parents and neighbours of the offenders (only the father of one offender) and the parents of the victim (mostly mother) are important actors. Others that are included are the then minister of justice, two former ministers of justice, and the children's rights ombudsperson.

It is important to note that although the young are the main topic of all these articles, they are not included as active participants. The issues connected with the young are the main topic, but there are no young people as actors; they are not included in the construction of the discourse. They 
were not interviewed and nobody included their attitudes and opinions about violence and about themselves and their problems. The only exceptions were two articles where certain statements of the young were included and they were able express their opinions about some of the topics. We can view this as a proof for the already mentioned idea that the young are mostly passive and nonactive actors in the media.

\section{Discussion and Conclusion}

Our aim has been to discover the image of the young created in a particular discourse about juvenile violence. Using discourse analysis we have concluded that the main actors are the writers, journalists, and experts from different fields, parents and public workers. These actors create a particular image of the young which strongly depend on the context, e.g. topic, main actors and coactors. The image of youth created here is a kind of "bipolar" picture. There is a strong division between the ways in which the victim and the violent young persons are presented, but a very strong "division" is also made between the victim and violent youth. When juxtaposed, the victim is depicted as a victim and the violent persons are rather criminalised. The victim is portrayed in superlatives; only positive aspects of his personality are stressed and there are no negative comments ${ }^{[23]}$ The picture of the victim is quite simple and very positive.

On the other hand, the image of the violent young is much more complex, and varies from a very negative one, "criminalised," to a not positive but acceptable one, accompanied with empathy and understanding. We believe that the analysis of syntactic functions and connected semantic roles and the analysis of lexical elements used to refer to the violent young persons shows in what ways the image of them varies depending on the context.

The violent youths are "criminalised" in certain contexts, e.g. when reporting about their behaviour in front of the courthouse (dancing and drinking), while in other situations they are victimised. When discussing the problem of juvenile violence in general, some of the writers try to identify the reasons for aggressive behaviour - parents who neglect their children, crisis in today's society, deterioration of the educational and school system, not strict enough laws - and all of the mentioned reasons are things which are beyond the power of the young to change. The young are depicted as victims who cannot do anything to improve their situation or solve the problem. 
Through such an image of young people as passive victims of different circumstances, they are shown as not being responsible for their own actions. Here we could discuss the possibility of symbolic violence ${ }^{24]}$ of the media over the young because of imposing such a passive image of a self who cannot make a difference.

Using such a discursive construction of the victim and the offenders, the identification with the victim and a kind of "taking sides" is expressed. Through such "taking sides" it is possible to see how writers position themselves towards the main problem of violence among the young but also towards the issues connected with it.

Media representation of young people is important because it can make an image of them accepted by adults and the young themselves. The media can influence taking certain actions in order to solve a problem; however, the influence can also be negative, mobilising the public to take negative actions. The negative influence can be seen in exaggerated statements about an increasing wave of juvenile violence in Zagreb or about the hooliganism of minors ruling the streets, including the statement that violent behaviour has even become completely normal in a modern society.

Through the analysis of discourse we can see how the problem of juvenile violence is presented in such a way that it produces strong public reactions. Figures and language elements that provoke shock and emotional reactions are usually used in headlines. Our analysis has also shown that in the marked parts of the texts (such as sidebars, or summaries) the problem of juvenile violence is very often presented in a dramatic way with elements of inducing moral panic, ${ }^{[25]}$ which can be defined as a "spiral in which the social groups who perceive their world and position as threatened, identify a 'responsible enemy', and emerge as the vociferous guardians of traditional values." (Clark et al 72)

Some of the news discourses try to cause panic by depicting the young as delinquents, as irresponsible, violent persons without respect for traditional rules and norms (Vuk 46). Generalising the problem, one is left with the impression that the whole young population is suicidal, violent, and irresponsible. If we take into account some of the details of the definition of moral panic, ${ }^{[26]}$ e.g. the fact that it is mostly oriented towards different subculture groups (in our discourse, the notion of 
subculture is not important), that it influences certain actions against the young (which has, again, failed to take place), presenting them as the "folk devils" who pose a threat to the norms of society (which again is not found in our corpus), it may be better to speak, in our case study, of press panic or panic in the press than of moral panic (Van Dijk, "News Analysis" 224).

In the media, juvenile violence has increased and the specific and different discourses about violent events in different places have created the impression that there are more violent acts than there really are. An argument that has frequently been used is that violence is on the increase in Europe as well. According to Estrada $(647,8)$, however, the view that juvenile violence in Western Europe is rapidly increasing is challenged because it has not increased in number, but "violent offending by young people suddenly becomes the focus for a great deal of attention" and this is what has changed the image of juvenile violence.

It is interesting to note that only one commentator is in accordance with the previous findings; he states that there is no more violence than before but the difference is that today's media report more often about it. He emphasises that the young "have not changed overnight and [that] good kids that everybody praised have not turned into little demons," but that the media use sensationalist headlines, which do not refer to the texts at all, only to attract attention. The main idea of this text is that '[e]xpressing shock over kids' fighting only proves that we have made progress in terms of civilisation," and that the conflicts among the young are not worse now than they used to be, but that we are more sensitised to violence. The conclusion is that "today's youth is crazy, but it is crazy for 'this' time. ${ }^{\lceil 27]}$

We can conclude that the young are presented as "Others" in relation to the adults who are the main participants in the discourse, first and foremost, because they create it. The adults decide what an interesting and relevant topic is and how it should be organised. With the help of language elements, the image of the young that is created is a picture of passive co-actors and victims.

The idea about the otherness of youth in Croatian media is supported by presenting the young as "young," meaning that age identity is the most important one for the main actors in the discourse. There is no mention of other elements of their identity; nothing is said, for instance, about the schools they attend, music they like, habits, etc. Their youth is the most prominent element of their identity and emphasising only this aspect of their identity restricts the possibility to see other 
elements. With stressing this one element they are grouped and marked only as the members of that one particular group. Such simplified view of the young and neglecting the diversity of their identity make the division between groups stronger and in such a way the Other remains the Other. Marking the young as members of only one group with which the writers cannot identify not only influences attitudes towards them as Others, but also affects which image of the young will be discursively constructed ${ }^{[28]}$

\section{Works Cited}

Anderson, Christina L. "Double Jeopardy: The Modern Dilemma for Juvenile Justice." University of Pennsylvania Law Review 152.3 (2004): 1181-1219.

Barhnart, Clarence L., and Robert K. Barnhart. The World Book Dictionary, Vol. 2. Chicago, London, Sydney, Toronto: World Book, Inc, 1987.

Barić, Eugenija, et al. Hrvatski jezični savjetnik. Zagreb: Institut za hrvatski jezik i jezikoslovlje, Pergamena, Školske novine, 1999.

Clarke, John, et al. "Subcultures, cultures and class." Resistance Through Rituals: Youth subcultures in post-war Britain. Eds. Stuart Hall, and Tony Jefferson. London and New York: Routledge, 1993. 9-79.

Earls, Felton J. "Violence and Today's Youth." The Future of Children. Critical Health Issues for Children and Youth 4.3 (1994): 4-23.

Estrada, Felipe. "Juvenile violence as a social problem: Trends, Media Attention and Societal Response." The British Journal of Criminology 41 (2001): 639-655.

Gilliam, D. Franklin Jr., and Shanto lyengar. "Prime Suspects: The Influence of Local Television News on the Viewing Public." American Journal of Political Science 44.3 (2000): 560-573.

Gilliam, D. Franklin Jr., and Shanto Iyengar. "Super-Predators or Victims of Societal Neglect? Framing Effects in Juvenile Crime Coverage." Framing of American Politics. Eds. Karen Callaghan and Frauke Schnell. Pittsburgh: University of Pittsburgh Press, 2005. 148-166. 
Hudeček, Lana. "Hrvatski jezik i jezik književnosti.“ Raslojavanje jezika i književnosti. Zbornik radova 34. seminara Zagrebačke slavističke škole, 2005. Ed. Krešimir Bagić. Zagreb: FF press, 2006. 57-79.

Hunt, Arnold. "'Moral Panic' and Moral Language in the Media." The British Journal of Sociology 48.4. (1997): 629-648.

Ilić-Šunderić, Ivana, et al. Istraživanje o položaju mladih u štampanim medijima u Srbiji. 2007. 27 June 2010http://grupaproces.org/grupaprocesmediji.pdf.

Ilišin, Vlasta. „Mediji u slobodnom vremenu djece i komunikacija o medijskim sadržajima.“ Medijska istraživanja 9.2 (2003): 9-34.

Kanižaj, Igor. Odgovornost i utjecaj medija u izvještavanju o djeci. 16 May 2010. 30 August 2010 www.obiteljskicentar.hr/media/attachment/IgorKanizaj_Djecaimediji.pdf.

Kladar, Anja. "Programi za mlade HTV-a, RTL-a i NOVE TV." Mladi i društvo - Pitanje identiteta. Bilten studija o mladima za mlade 01. Ed. E Bužinkić. Čakovec: Mreža mladih Hrvatske, 2010. 116- 119.

Knežić, Branislava. "Od definicije do operacionalizacije, sa osvrtom na istraživanje nasilja." Temida 1 (2004): 45-50.

Krisberg, Barry, et al. Youth Violence Myths and Realities: A Tale of Three Cities. Washington, DC: National Council on Crime and Delinquency, 12 February 2009. 12 December 2010 www.nccdcrc.org/nccd/pubs/2009_casey_youth_violence_report.pdf

Mediacentar Sarajevo. Mediji o maloljetnicima u sukobu sa zakonom. Analiza praćenja slučajeva maloljetničkog sukobljavanja sa zakonom u štampanim medijima u BiH. 2005. 27 June 2010 http://www.media.ba.

Mihaljević, Milica, and Barbara Kovačević. "Frazemi kroz funkcionalne stilove." Jezik 53.1 (2006): $1-14$.

Mladenov, Marin. Novinarska stilistika. Beograd: Naučna knjiga, 1980.

Nelson, Thomas E., Rosalee A. Clawson, and Zoe M. Oxley. "Media Framing of a Civil Liberties Conflict and Its Effect on Tolerance." The American Political Science Review 91.3 (1997): 567-583. 
Ochs, Elinor. "Narrative." Discourses as structure and process. Ed. Teun A. Van Dijk. London: SAGE Publications, 1997. 185-207.

Pizarro, Jesenia M., Steven M. Chermak, and Jeffrey A. Gruenewald. “Juvenile "Super-Predators" in the News: A Comparison of Adult and Juvenile Homicides." Journal of Criminal Justice and Popular Culture 14.1. (2007): 84-111.

Rapport, Nigel, and Joanna Overing. Social and Cultural Anthropology: The Key Concepts. London and New York: Routledge, 2000.

Sen, Amartya. Identitet i nasilje: Iluzija sudbine. Zagreb: Poslovni dnevnik, Masmedia, 2007.

Solar, Milivoj. Teorija književnosti. Zagreb: Školska knjiga, 1980.

Stokes, Jane. How to do Media \& Cultural Studies. Los Angeles: SAGE, 2003.

Thompson, Carol Y., Robert L. Young, and Ronald Burns. "Representing gangs in the news: Media construction of criminal gangs." Sociological Spectrum 20 (2000): 409-432.

Tomić-Kuludrović, Inge, and Anči Leburić. Skeptična generacija: životni stilovi mladih u Hrvatskoj. Zagreb: AGM, 2001.

Turjačanin, Vladimir, Trninić, Bojana, and Čekrlija, Đorđe. Mladi i mediji. Banja Luka: Helsinški parlament građana, 2005. 27 June 2010

http://www.mladi.info/files/pdf/lzvjestaj,\%20mladi\%20i\%20mediji.pdf

Van Dijk, Teun A. News Analysis. Case Studies of International and National News in Press.

Hillsdale, New Jersey Hove and London: Lawrence Erlbaum Associates, Publisher, 1988.

Van Dijk, Teun A. News as discourse. Hillsdale, New Jersey Hove and London: Lawrence Erlbaum Associates, Publisher, 1988a.

Violence Prevention Alliance, Department of Violence and Injury Prevention and Disability. WHO Definition and typology of violence. 13 December 2010 http://www.who.int/violenceprevention/approach/definition/en/index.html Vromen, Ariadne. "Three political myths about young people." Digest, 26 March 2004. 30 August 2010 http://www.australianreview.net/digest/2004/03/vromen.html 
Vuk, Ivan. "Moralna panika." Mladi i društvo - Pitanje identiteta. Bilten studija o mladima za mlade

01. Ed. E Bužinkić. Čakovec: Mreža mladih Hrvatske, 2010. 44-47.

Žižek, Slavoj. O nasilju. Zagreb: Naklada Ljevak, 2008. 
[1] www.zkm.hr

[2] The words of L. R.'s mother from the articles "Suzana Ritz: We are stronger than violence among the young" Jutarnji list, 7th October 2009 and "Mother of Luka Ritz: State institutions do nothing to prevent violence among the young" (www.index.hr, 14/11/2009), and from the TV show Latinica dedicated to the problem of violence entitled "There is no excuse for violence", 17/1/2011(www.hrt.hr).

[3] C.f. Ilišin.

[4] C.f. Gilliam and lyengar, "Prime Suspect" 560.

[5] This is something we noticed during data collection; it was rather easy to find an abundance of articles about juvenile violence. There were a lot of texts dealing not only with the case of L. R. but also with other violent acts. We did not closely examine all the articles about the young, but it was obvious at first glance that there were more articles about their problems, especially violence, than about good and positive experiences. This can suggest the interest of society in the problems of the young.

[6] C.f. Kanižaj.

[7] In discourses mainly about young offenders it is expected that they occupy the subject position because it is also the position for the topic role. In our corpus, there are only a few instances where the offenders are not in the first position in the sentence, e.g. Detained attackers on Luka Ritz (literal translation), in which the role of the police is stressed.

[8] Here we can also speak of an instance of breaking the journalist code by referring to the defendant as guilty even before the trial against him/her has started.

[9] "The three are on trial for the death of Luka Ritz 15 months after the beating on the bridge", Večernji list, 5/9/2009. L. R. was described as a kind person, an artist at heart, a good schoolboy who intended to study journalism and be a rock critic. In a commentary by M. Jergović "Angels are killed in Zagreb," L. R. was presented as a "quiet, well-behaved and educated boy." Jutarnji list, 19/6/2008. 
[10] "Luka's death proves that Zagreb is not a safe city", Večernji list, 8/9/2008.

[11] The underlining is ours. From the article "My son turned grey during the 90 days in a cell with criminals" Večernji list, 18/8/2009.

[12] It is only in texts dealing with the public initiative that demanded a harsher law on juvenile delinquency that certain elements of criminalisation could be seen. "A minor who kills somebody is not a delinquent but a killer!" www.index.hr, 1/3/2010.

[13] "Broken-hearted parents: Parents of the killers: Let them serve a 50-year sentence" www.ezadar.hr, 22/10/2008.

[14] Ibid.

[15] "Violence among the young: Alone, neglected and dangerous!" Večernji list, 16/12/2009.

[16] Ibid.

[17] "Killers of Luka Ritz are not the exception but the tragic rule" www.index.hr, 22/10/2008.

[18] "The young repay with violence for the society's 20-year-long neglect" www.index.hr, $3 / 11 / 2008$.

[19] Ibid.

[20] Van Dijk ("News as Discourse" 5) also distinguishes newspaper articles with informative function in the narrow sense, which include news about political, social, or cultural events, as well as editorials, background texts, columns, non-editorial opinions, etc.

[21] $16 / 6 / 2008$

[22] Večernji list, 25/9/2008.

[23] This can be seen very well from the article published on the front page of Večernji list, 30/9/2008, under a rather sensationalist headline "Exclusive: Parents reveal the family secret: Luka Ritz donated his organs." In this, two pages long text about the wish of the late L. R. to donate his organs after his death, the positive image of the victim is even more stressed.

[24] Žižek (7) defines symbolic violence as the kind of violence embodied in language and forms. 
[25] Cf. Mediacientar.

[26] For more details see Hunt.

[27] "Before they were crazy as a pinball machine, and today as a PS3" was the comment by Hrvoje Marjanović for www.index.hr, 25/11/2008.

[28] This conclusion about stressing just one element of the Other's identity and, in this way, marking the difference between "us" and "them" is influenced by the theory of Sen. He states that the illusion about Others as members of only one group, negating other elements of their identity, brings the perception of distance and disagreement with the others.

\section{cc) $(1) \ominus$}

Creative Commons Attribution-NonCommercial-NoDerivatives 4.0 International License 